\title{
STUDY PRACTICES AND THE CREATION OF A COMMON WORLD. UNEARTHING THE EDUCATIONAL DYNAMICS OF AN URBAN FARMING INITIATIVE
}

\author{
Prácticas de estudio y la creación de un mundo en común. \\ Desvelando las dinámicas educativas de una iniciativa de \\ agricultura urbana
}

Hans SCHILDERMANS, Joke VANDENABEELE, Joris VLIEGHE

Katholieke Universiteit Leuven. Bélgica.

hans.schildermans@gmail.com,Joke.vandenabeele@kuleuven.be, Joris.vlieghe@kuleuven.be

bttps://orcid.org/0000-0003-4408-523X, bttps://orcid.org/0000-0001-8855-3571, bttps://orcid.org/0000-0001-6307-3221

Fecha de recepción: 23/07/2919

Fecha de aceptación: 14/08/2919

Fecha de publicación en línea: 05/09/2019

\section{ABSTRACT}

In this article, we propose study practices as a way to respond to the question Bruno Latour raised with regards to our current global predicament, namely where to land? In the first sections we explain the background of this question - socio-ecological challenges and transformations - and how study practices might help to offer an answer. The subsequent section sheds light on the theoretical developments in relation to which the notion of study practice has been conceived in the first place, in particular the methodological debates which saw a turn to practices on the one hand, and the theoretical discussions about the concept of study on the other hand. Analysis of the urban farming initiative torekes in terms of a study practice allows for fleshing out the educational dynamics at play in such practices: composition, problematization, 
and attention. We contrast such an educational analysis with sociological and political analyses that understand this initiative as aimed at social cohesion or political subjectification respectively. In the last section, we argue how study practices, due to the ways in which they allow for the creation of a common world, might provide a response to the question how to live together on a damaged planet.

Key words: study practices; political subjectification; social cohesion; attention; urban farming; Isabelle Stengers; Bruno Latour.

\section{RESUMEN}

En este artículo, proponemos una serie de prácticas de estudio como respuesta a la cuestión que planteó Bruno Latour respecto al dilema actual al que nos enfrentamos en todo el mundo; es decir, ¿đónde aterrizar? En las primeras secciones, explicaremos el fondo de esta cuestión (los retos y las transformaciones socioecológicas) y cómo pueden ayudar las prácticas de estudio a ofrecer una respuesta. La siguiente sección arrojará luz a los desarrollos teóricos en relación con aquello para lo que la noción de la práctica de estudio ha sido concebida en primer lugar, en concreto los debates metodológicos que presenciaron una vuelta a las prácticas por un lado, y los debates teóricos sobre el concepto del estudio por otro. El análisis de los torekes de la iniciativa de agricultura urbana en términos de una práctica de estudio permite desarrollar la dinámica educativa en juego en dichas prácticas: composición, problematización y atención. Contrastaremos dicho análisis educativo con diferentes análisis sociológicos y políticos que entienden que esta iniciativa pretende la cohesión social o la subjetivación política respectivamente. En la última sección, argumentaremos cómo las prácticas de estudio, debido a las formas en que permiten la creación de un mundo en común, pueden proporcionar una respuesta a cómo vivir juntos en un planeta dañado.

Palabras clave: prácticas de estudio; subjetivación política; cohesión social; atención; agricultura urbana; Isabelle Stengers; Bruno Latour.

\section{INTRODUCTION}

In this article we want to lay the conceptual groundwork for developing a new understanding of contemporary educational initiatives that respond to pressing societal issues and that take place outside of formal educational settings. We call these initiatives study practices. We do this because the learning that happens here could be analyzed as a collective endeavor of people who are affected by an issue which is related to a concrete place they inhabit and which moreover forces them to think and come up with ideas that make a difference to the situation they are finding themselves in. Study practices bring together scientific and political processes: they are about the creation of new knowledge, and they want to envision new ways of living together, so as to grant the possibility of different futures. But, we claim that 
these practices are also different from both scientific and political practices ${ }^{1}$. Study practices have their own logic and this sets them apart from the other two practices (they are also more than a mere combination of both practices). This makes them an educational phenomenon through and through. It is this properly educational dynamics that we want to analyze in the following.

In order to give the reader a more concrete idea of what we are talking about, one could think of an initiative that was recently developed in an urban context in which people with a migration background gather around the immaterial heritage of their country of origin. Together they exchange certain skills and crafts, and investigate what the meaning of this heritage could be for their new living conditions. Another example concerns a forum that is set up in a collaboration between academics and representatives of the public in order to respond to the housing crisis their city is currently experiencing. They map actual dwellings, housing policies, and potential lacks, and also envisage alternative forms of housing that could be relevant to the context they are studying. One could also consider the example of an organization that brings together youngsters from different backgrounds to document and analyze their lives in a metropolitan context. Together they make films which bring forward the ways in which living together, including the concerns it entails, takes shape in their city. As such they are offered the opportunity to think in new ways about the issue of how to gain representativeness. As a last example, one might consider a project in which an alternative currency was devised for and by communities living in marginalized neighborhoods and in which a small-scale, exchange system was set-up based on urban agriculture. This allows them to reconsider the meanings of money, work, value, and volunteering.

These study practices have in common that they are concrete answers to issues that entail an enormous challenge to common life on this planet - and with this we mean both living together with other human beings and with all the beings that are not-human: the impact of mass migration, superdiversity, sustainable food supply and exchange of goods, etc. After analyzing in greater detail these challenges with the help of the recent work of Bruno Latour, we explain more substantially why we propose to regard them as study practices (by carefully investigating the notions of practice and study), so as to draw out the specific educational meaning of study practices. We are indebted here to ideas developed in the work of Isabelle Stengers. A substantial part of this article concerns an analysis of one of the four aforementioned illustrations (viz. the urban agriculture initiative that developed an alternative currency) in order to unearth the educational dynamics of study practices and conceptualize how they respond to current socio-ecological challenges.

1. Scientific practices, according to our definition, are concerned with gaining a fuller understanding of the world: they concern practices that are undertaken either out of a pure theoretical interest (knowledge for the sake of knowledge) or out of the expected solutions one can find by applying knowledge to concrete problematic situations. Political practices could be defined as collective practices in which people try to make a difference to the quality of their common lives, either through discussion or, more directly, by undertaking action that might change the opinions of the populace and/or policymakers. 
HANS SCHILDERMANS, JOKE VANDENABEELE Y JORIS VLIEGHE STUDY PRACTICES AND THE CREATION OF A COMMON WORLD. UNEARTHING THE EDUCATIONAL DYNAMICS OF AN URBAN FARMING INITIATIVE

\section{LIVING TOGETHER ON A DAMAGED PLANET}

Our argument starts from the recent work of Bruno Latour, Down to Earth. In this book he argues that all major societal issues - mass migration, growing inequalities, global deregulation, climate change denial, the rise of populism and ethnic intolerance - find their root in the new condition we are faced with: we experience to live on a damaged planet and hence we have no more - or not enough - soil or territory to live on decently. Otherwise put: we have all become migrants, even those who still believe to have firm ground under their feet (Latour, 2018).

The increase in planetary inequalities and deregulation, Latour argues, can be explained as the result of the industrial elites that have come to realize that there is not enough space left to guarantee a respectable life for all (although it is in their benefit to publicly deny climate change and to convince others of this too). Hence they have withdrawn within their gated communities to live a good life in isolation from all the rest, with whom they no longer want to share anything (e.g. redistribute wealth or protect the working class through legislation). On the other side, large groups of people who are bereft of the possibility to inhabit the earth, desperately look for a soil where they can dwell again in fair circumstances. Hence the recall to ethnocentric and nationalist discourses and the fear for streams of immigrants that come and take away the last piece of land they still think to possess.

The important part of Latour's analysis we want to take up further is that this whole situation is supported by an erroneous, but powerful representation of what it means to live on earth. It regards a picture of the world that has held us captive since Modernity and that is supposed to guide or orient us when defining our struggles. Very briefly put, for centuries we have defined our political objectives in terms of a tension between the Local and the Global. Modernization could be defined as a process moving forward from Local attachments (e.g. to local traditions, values and places) to a global orientation point: the idea was that we all have to emancipate ourselves from these local attachments, which are felt as 'backward', 'irrational and 'unenlightened', in order to become citizens of the world that are solely attached to the universal and decontextualized values of Reason, so that we can realize, on the Globe, a prosperous life for all based on the fruits of western science and technology (Latour, 2017, 2018).

However, for many people this scenario sounds undesirable, not in the least because it is an unfeasible dream - especially as it has become clear today that the earth is not large enough to realize modernization at a planetary scale. In view of the real-life effects of modernization they experience on a daily basis, it becomes understandable that they want to re-attach to their own local traditions, values and soil. Hence there is an intelligible reflex to promote the Local over the Global. This tension between globalization and localization can also be easily rendered in terms of progressivism and conservatism or the left and right wing opposition (economically speaking at least). Vital to Latour's analysis is that this way of rendering what is at 
stake in our struggles has no ground in reality - and it never had: it is a Modernist fiction. In reality, it has never been possible to really inhabit the Globe, to the same extent that it is utterly impossible to live closely secured within the safety of sealed-of Local confines.

Therefore, we have to reorient ourselves, i.e. we need to get an idea of the real stakes of our struggles. For Latour the tension that matters is not the one between the Local and the Global, but between the bottomless 'out-of-this-world' position (shared by the elites and climate change deniers) and the terrestrial, the earthly. What is needed today is that it becomes possible to land again on earth, albeit not on the fictional Local enclosure or the Globe Modernists dream of, but on a concrete place that comes to matter to us and for which we want to take communal care. Latour is inspired here by the so-called critical zone observatories, which are small-scale transdisciplinary science initiatives to collectively investigate a part of the earth's crusts and atmosphere (critical zone) and map the impact of a changed climate on this area. Importantly, it regards a collective endeavor of research activities that wants to respond to a pressing societal issue, that moreover offers a sense of attachment to a particular place (the terrestrial) and that can make a real - even though small - change to living together (with other human and non-human inhabitants) there (cf. Arènes, Latour, \& Gaillardet, 2018; Latour, 2018).

We propose in this article that there are many small-scale initiatives taking place today that address major societal, economical, ecological, etc. issues in a similar way: they gather people around an issue that comes about at a specific place, in order for them to investigate and to engage in inquiry and deliberation, so as to form concrete ideas about how a life in common can be given shape differently (cf. Tsing, Swanson, Gan, \& Bubandt, 2017). As we said, these initiatives could be situated at the intersection of what is traditionally called scientific and political practices (and that is also what Latour hints at). But, we are interested in a dimension of these practices that exceeds the level of politics and knowledge production (or the alliance of both). Hence, we want to investigate them as study practices - practices with their own educational dynamic.

More exactly, in these practices people come together around an issue that concerns them, but not in order to give an immediate response. Instead they slow down, take their time in their common investigation of the issue at hand: they experiment so to speak (meaning that there are no predefined answers, or that one has no inkling at the beginning where the process will take them). Experimentation also means stumbling, hesitating, making mistakes. At the same time they become attentive for and attached to the place where the issue under investigation comes to the fore. All these aspects are typical for what studiers do, and hence these practices could be called practices of study. 
HANS SCHILDERMANS, JOKE VANDENABEELE Y JORIS VLIEGHE STUDY PRACTICES AND THE CREATION OF A COMMON WORLD. UNEARTHING THE EDUCATIONAL DYNAMICS OF AN URBAN FARMING INITIATIVE

\section{SITUATING STUDY PRACTICES WITHIN AND BEYOND CURRENT DEBATES}

In this section, we want to situate our approach against existing literature in educational theory and philosophy in which in recent years both study and practices have become important concepts. Nevertheless we want to show that our focus on study practices takes the existing approaches in new directions. Whereas the first subsection is more methodological in scope in its orientation on practices, the second subsection puts forward the basic tenets of the concept of study.

\subsection{Practice-oriented approaches}

In recent years, there has been increasing attention for practice-theoretical approaches to educational phenomena (cf. Higgs, Barnett, Billett, Hutchings, \& Trede, 2012; Kemmis, Wilkinson, Edwards-Groves, Hardy, Grootenboer, \& Bristol, 2014). This is not a new trend, but goes back to the attempts at the end of the $20^{\text {th }}$ century to find a middle way between totalizing social ontologies on the one hand, and individualizing social ontologies on the other hand (with 'society' and 'the individual' as its prime referent respectively). There are many practice theories (cf. Postill, 2010), but three features that seem to be shared by all are, firstly, the fact that different people and things are involved and brought together by an activity that unfolds according to a more or less organized structure. It is assumed that the people engaged in the activity know the tacit rules of the activity which not only means that they know what to do and how to do it but also that they know how to go on with the activity given unforeseen circumstances. The second feature is that important characteristics of human life or social phenomena such as science, power, and social change must be understood as rooted in the organized activities of multiple people and things. A person's individual behavior cannot, for instance, be understood outside of the context of the practice in which this person participates, together with other people and things. From a methodological point of view, this means that practice theorists will focus for instance not so much on science, economics, or politics in general, but rather on specific scientific practices (e.g. conducting an experiment), on economic practices (e.g. negotiating a price), and on political practices (e.g. a debate in the parliament). The last basic tenet of practice theory is that human activity rests on implicit rule-following and knowing how to go on. Being involved in practices involves not so much having a clear idea about its meaning, but rather being capable of performing the activities of the practice in conformity with established expectations that define a particular practice (cf. Ortner, 1984; Schatzki, 2012; Schatzki, Knorr Cetina, \& von Savigny, 2001).

The practice theory of the Belgian philosopher of science Isabelle Stengers is according to us of particular interest as it sets a step further than more classical practice theories that are often rooted in philosophy of language (cf. Wittgenstein's language games) or in anthropology (cf. Garfinkel's ethnomethodology). Stengers 
understands practices not just merely in terms of the rules that are followed or the norms that guide the practice. Instead, by differentiating between requirements and obligations of a practice, her approach allows for understanding how a practice works ('requirements') as well as for grasping what is at stake within a practice ('obligation'). The notion of rule, according to her, risks to put all practices on the same plane of being social practices. Such an approach focuses too much on what makes practitioners converge (cf. rule-following, knowing how to go on, etc.) and neglects that which makes practitioners hesitate, disagree, diverge. In other words, the requirements of a practice denote those features that hold the practice together, the often tacit rules and ways of doing that allow practitioners to go on, even in case of unforeseen circumstances. The obligations, on the contrary, make practitioners diverge, in the sense that they denote what is at stake within a practice, that which about there is no consensus, but rather requires thought and discussion (Stengers, 2006, 2010). As such, Stengers adds the notion of obligation to the rule-based understanding of practice. An obligation is something that makes practitioners diverge in spite of the requirements that grant stability to a practice. In short, whereas the requirements identify the how? of a practice, the obligations define the what? of a practice.

\subsection{The re-emergence of study}

In much recent scholarship in philosophy of education and elsewhere (Harney \& Moten, 2013; Lewis, 2013, 2014; Masschelein, 2017; Simons, 2017; Cf. Ruitenberg, 2017) the very notion of study has received renewed attention. To these authors this is because this terminology seems an adequate expression to capture an activity deployed in contexts of formal education (and especially in universities) which we hold dear but which is at risk of being suppressed or forgotten about. They argue that this is due to the dominance of a discourse of learning, well supported by policy makers and educational scientists alike, which boils down to the idea that education is essentially about gains in knowledge, competence and skill, which are to the benefit of individual learners. Conversely, all issues that challenge a communal life are rendered as individual learning problems. This process of learnification makes us blind for particular aspects of education that seem to matter (or to have mattered) and which transcend the focus of individual learning outcomes.

Historically speaking and in support of their argument, studying seems (to have been) an activity that was opposed to learning the way it has taken shape today (within the dominant discourse). One may think here of the study practices that were developed with the invention of the European university in the 12th century. As Illich (1973) wants it in Deschooling Society:

[T] he university protected an individual's freedom of speech, but did not automatically convert his knowledge into wealth. To be a scholar in the Middle Ages meant to be 
poor, even a beggar. [...] [The university] was a liberated zone for discovery and the discussion of ideas both new and old. Masters and students gathered to read the texts of other masters, now long dead, and the living words of the dead masters gave new perspective to the fallacies of the present day. The university was then a community of academic quest and endemic unrest (p. 41).

People from all walks of life and from far and wide in the then known world gathered to devote their life to inquire without any guarantee of a specified outcome, let alone the strengthening of individual positions. Illich suggests that these first universities were places of potential insurrection: by withdrawing from the daily business of the world and by fully committing oneself to study, it became possible to take distance from the given order of things, and to start conceiving of ideas that might go against the way individual and collective life is customarily organized. This implied a particular organization of time and space, which involved study material (a canon of texts), places to be physically gathered around this material, and an organization of time which allowed studiers to think, to stumble, to ruminate.

So, seen from such a historical angle, it becomes clear that study might offer a promising alternative to the dominant discourse that stresses individual learning gains and that puts forward an artificial bifurcation between learners and providers/ facilitators of learning (teachers and lecturers). Moreover, the language of study might reconnect to the critical, sometimes insurrectionary and above all ideas-generative potential of what we do in schools and universities today. Hence, it is no surprise that many scholars today show an interest in study from the perspective that it regards a specific pursuit with its own decisive and unique logic, e.g. when Tyson Lewis $(2013,2014)$ argues that study is about a complete immersion into something which makes one forget about the need to achieve, about the pressure of (productive) time and about whatever societal duties one has, and which comes close to the state of being-addicted (whereas learning, according to Lewis, is always a protection against this addictive immersion). Study is essentially self-loss and suspension of the societal order.

Or, as Jan Masschelein (2017) suggests, studying captures much more than learning what universities are all about, because studying is an autotelic activity which moreover demands that one starts caring for the world and thinking publicly. Study is about making present a particular aspect of the world (e.g. during a lecture or a seminar, or any other pedagogical form that is aimed at generating collective attention for the world), while at the same time addressing and discussing about difficult issues concerning how to live together with that what is brought under our attention. Lastly, we could mention here the work of Derek Ford (2016), who analyses the dominant discourse on learning as testifying to a logic which supports the societal fabric of capitalist societies. Hence, he opposes learning to study, which in his book is always communist and which is the core formative activity of people that engage in revolutionary struggle. 
The turn to study practices we advocate in this article fits in well with this recent reclaiming of the notion of study. However, we also want to set a step further and to develop the notion of study in new directions. First, although we agree that the original context within which this concept got its meaning is the world of formal education, and the university more specifically, we argue that study also takes place outside of the world of schools and higher education. Many of the characteristics outlined above are apt descriptors of activities we see happening today in contexts of non-formal education, where a public is gathered to think about pressing contemporary issues, and where they take the time and the opportunity to explore, to inquire, to discuss, to hesitate, etc.

Second, although some of the above mentioned authors point towards the collective and democratic dimension of study, this is not necessarily the case in their accounts: often study is portrayed in terms of the iconic scholar who is represented as a solitary and heroic, unique and exceptionally brave and talented personality (cf. Lewis, 2013). We, however, hold that study is by definition a joint enterprise that concerns literally everyone affected and that sets no a priori limits to who can be a studier: it is more the case that precisely because and in so far that we are all incompetent in view of a troubling situation (cf. Callon, Lascoumes, \& Barthe, 2009), that we are equally and as a collective involved in study practices.

Third, contrary to what is suggested by most authors that have rediscovered study, we are not opposed to learning as such. On the contrary, what we suggest is that learning takes place while studying, but that the stress should be not so much on the learning outcome (related to the individual studier), as it should be on the possibility which comes about to see the world with fresh eyes. Hence, it seems more accurate to conceive of studying in terms of learning anew (cf. Schildermans, 2019). What happens here is learning, as it demands that we become transformed by taking the situation seriously. But, we also become affected - or to put it still in other words: as studiers we are being taught by the situation and its demands, and hence we learn anew. We become sensitive to what is possible in a given situation.

\subsection{Study practices}

Bringing together the practice approach we developed in 3.1. with Isabelle Stengers and the redefinition of study discussed in 3.2., we want to suggest that the notion study practices grants a not yet explored opportunity to theorize initiatives deployed in non-formal educational contexts which gather a thinking public around a local matter of concern in order to come up with new ideas to address a problematic situation they find themselves in. Although, the notion of study does not appear in the work Stengers because she does not define herself as an educational theorist, we are convinced that her thinking can be brought to bear on educational issues.

Study practices are not gratuitous endeavors (a notion that might be wrongly come to our minds when solely thinking about study in terms of the solitary scholar 
toiling in the library). Study practices are constituted through the mutual ensnaring of obligations and requirements. With this, we want to remind, that in practices of study there is always something at stake that necessitates us to start inquiring, thinking and discussing. But this should also be clear from the specific efficacy of study. Whilst studying, people become response-able: they become capable of addressing the troubling situation they are in by formulating new ideas that entail concrete responses to the specificity of the situation and that, above all, allow them to imagine a world that does not coincide with the given order of things (and the solutions to their problems that are almost inevitably implied). It regards, thus, a strong sense of ability, as it grants the possibility to start anew with the world - and not to accept any situation or solution as unavoidable (Haraway, 2016). In this context, Stengers (2002) remarks that thinking is "to create possibility against probability» (p. 245). This is to say that on the basis of a given definition of the situation we can easily exclude many options as improbable and embrace a 'there is no alternative' approach. But, this is an immunization against true thinking. For Stengers, thinking stems from the willingness and desire to be addressed by the situation itself and the possible that is present there (and hence to leave behind the definitions we already have).

\section{STUDYING IN THE SOIL, THE CASE OF TOREKES}

Returning to the question of Latour of finding a place to land, our aim is to present at this point an urban farming initiative that according to us can be described as a study practice. Analysis of this case allows for unearthing the educational dynamics at play in the theoretical framework elaborated above in relation to a specific case, and for speculating about the ways in which such study practices operate as 'landing strips' (in the Latourian sense), or as creators of common ground. The case we wish to introduce is the initiative of torekes in the Belgian city of Ghent.

\subsection{Situating torekes}

As a way of addressing the issues of poverty, labour market exclusion, and deterioration of public spaces in the neighborhood Rabot-Blaisantvest in Ghent, a community work organization ("Samenlevingsopbouw») chose to implement a complementary currency, called "torekes" (literally "small towers", referring to an ancient lock near the neighborhood). This neighborhood of Rabot-Blaisantvest has the highest percentage of ethno-cultural minorities and non-Belgians of all neighborhoods in Ghent. The number of people with the right to social security and the risk of unemployment is also one of the highest in Ghent, and the average net taxable income is the lowest in Ghent. torekes allowed for creating and sustaining an additional economy, next to the regular economy. It is important to note that this complementary currency was not intended to suppress the regular economy of global financial markets, regulated labor, and employment laws, but that it 
provided a means to reward work that was done voluntarily in the neighborhood. The observation was indeed that the inhabitants of the neighborhood often did not have a lot of money, but instead they were rich in time (Depraetere, Van Bouchaute, Oosterlynck, \& Vandenabeele, 2018). Implementing the torekes allowed for rewarding people to invest time in taking care for their neighborhood, and although the rewards were small, they allowed them to improve their quality of living. With the complementary currency, they could buy extra goods or services in local shops that would accept the money. There is an exchange rate between the torekes and the regular Euro system: ten torekes have a commercial value equal to one euro. Because of the intention to stimulate local exchange circles, only the merchants can directly exchange their received torekes for euros. In the literature, the case of torekes is often analyzed in terms of social cohesion or political subjectification. We contend, however, that analyzing torekes as a study practice articulates its educational efficacy more strongly ${ }^{2}$.

\subsection{Three dimensions of the educational dynamic of study}

In the following analysis we shed light on the educational dynamics at play in the torekes initiative. Based on previous research, we chose to analyse this case along three axes that correspond with three dynamics of a study practice in particular: composition, problematization, and attention (cf. Schildermans, 2019; Stengers, 2017). In our analysis, we start from a few observations that have been made on the site and try to grasp what happened in terms of composition, problematization, and attention. It will become clear that at face value, the project lets itself be understood quite easily as community work aimed at social cohesion. This is also an interpretation often given by the social workers on this site. By identifying and differentiating these three dynamics, however, we show that torekes not only fosters community development, but also processes of questioning and investigation. The three dynamics outlined above and explained below are - in their mutual reinforcement - particular to study practices.

2. One of the authors of this article got the opportunity to document this case as part of a research program on 'Diversity and Community Development'. Hence, we had access to policy documents on the Torekes initiative, to the annual evaluation reports written by community workers and to media communication (website, catalogue, movie, brochures etc.). In addition to this, our analysis is based on a focus group discussion in which eight Torekes volunteers participated, and on interviews that were done with the initiators of the Torekes project, the community workers that carry out the project and their local partner organizations. Finally, a PhD-researcher conducted a participatory field research and worked for four months on the communal agricultural fields. 


\subsubsection{Composition}

First and foremost, it should be noted that the efficacy of torekes as a complementary currency did not stand on its own, but went hand in hand with public investments in green public space of which the former Alcatel factory is especially worth mentioning. This factory has been completely demolished, except for the concrete floor of one and a half hectares. A specific composition of people, things and activities became possible on this floor as fertile soil was spilled out on almost one third of the total surface area. A large greenhouse,160 allotment gardens, two communal agricultural fields, a city farm with eight chickens, a football field, a huge sandpit for children, a bread oven, and a tool shed were constructed on this soil.

Since the introduction of the torekes, more people from more diverse backgrounds came to gather on this place and made use of the soil and the constructions built there. People from the Turkish community for example, most of whom are originally from the agricultural area of Emirdag, were attracted to the allotments and communal agricultural fields, especially since most of them do not have a garden themselves. A number of older middle class Belgian women organized on a regular basis a give-away shop on this place. They also worked on the communal fields and in doing so, earned torekes to rent an allotment garden. Residents living in a disadvantaged situation also came and worked on this place because of the currency's effect on their income. A community worker sums up: "A person with a Turkish background who speaks little Dutch, a homeless Belgian man and a Nigerian refugee. These various figures swarm around on the place, and are linked to each other through the torekes" (Depraetere, Van Bouchaute, Vandenabeele, \& Oosterlynck, 2014, p. 9). The most salient characteristic of this green public space is that it draws people out of their private houses and brings them together in a space that is shared. However, it is important to emphasize that people are not just hanging out together, or that they talk and converse with each other, but that they submit to the rhythm of labor in which working the soil and having a break together alternate.

Here we discern a first dynamic at play, which we conceptualize as a form of composition. It concerns the way in which people, animals, machines, and things are brought together, and how they come to relate to each other. Think for instance of the emergent relations between the former inhabitants of Emirdag, the allotment gardens, spades and shovels, white middle-class women, and chickens. As such, composition regards the concrete socio-technical arrangements without which there simply would be no studying: a structured fitting-together of human and non-human constituents within a specific place, the former factory site. Studying in this view is hence not a spontaneous and self-sufficient activity of a solitary mind that enjoys its own power of abstraction and reflection, taking a noncommittal and complacent attitude towards other thinkers and the world. Instead, studying demands that the studier gets addressed by others and by things that force her to speak, think and relate to others and the world in particular ways. It is important to note that such a 
composition is not something like a container, a recipient for gathering non-related stuff, but rather that it is due to the rhythmic quality of the composition (think for instance about the alternation of work and pause, of silence and chit-chat) that relations are forged and come into being. Composition, hence, does not only stress the interdependency of a myriad of relata, but also the generative quality of those interrelationships.

This generative aspect is clear from the fact that the inhabitants of RabotBlaisantvest are not only focused on living a decent daily life (e.g. being able to buy a bus ticket with torekes or eat fresh vegetables), but are also contributing to a common world. For example, people picnic together and share their food. Once, a volunteer also saved his torekes in order to be able to treat his fellow volunteers with a meal in the local social restaurant. That same volunteer bought a bike for the son of a fellow volunteer who was not able to pay for one himself. Even the weeds that are pulled out, become part of a common world and are for example used to bake breads for everyone who happens to be present on this place. One of the community workers explains:

At a certain moment an old woman came to ask for something in Turkish and we couldn't understand one word of it. So we called someone who could translate. She was asking whether she could have the weeds that grow between those potatoes. We said yes but also indicated that she, of course, had to weed herself. The next day she was back here and brought mega big breads baked with this weeds, to show "what she can do with this weed'. And again everyone was invited around the table and eat these breads (Depraetere et al., 2014, p. 21).

These occasions where residents with diverse backgrounds start to mingle and talk to each other are important in that they support the collective quality of the torekes initiative. But, this dynamic by itself does not make this practice into a study practice, as that would require two other dynamics.

\subsubsection{Problematization}

This means that it is necessary to elaborate on a second dynamic, which makes it possible to differentiate the torekes initiative from other community work practices. torekes did not only cause people to come together outside their private homes (a classical social cohesion objective). Rather, the gathering of people, things and activities on a former factory site made people start raising questions concerning what is really at stake in this particular neighborhood. People began to slow down the smoothness in which services and goods got exchanged via torekes. During one of the encounters between a researcher and torekes volunteer, one participant interrupted the conversation and said: "The most important question to ask here is 'why don't they give us euros?'” (Depraetere et al., 2018, p. 103). Similar questions came to the surface during the fieldwork as some of the participants for example 
clearly thought the remuneration was too low. One of them seriously suggested to go on a strike in order to get a better wage: "If the city's civil servants can decide to strike, why can't we?» (Depraetere et al., 2018, p. 103). What these utterances show is that inhabitants became sensitive to issues related to the value of work. Indeed, questions such as why payment for voluntary work is done in torekes and not in Euro demonstrates that they became attentive to the meaning of labor and how it should (or should not) be rewarded in monetary terms. Besides, the project raises a sense of awareness of difference between global capitalist economies, and the local economy of Rabot-Blaisantvest and the importance of taking care for the place.

Problematization, hence concerns the way in which a problematic situation can be given the power to make a public think. In this case, the questions raised by the people concerning the nature of their work (voluntary or paid) and the way it is being rewarded (in Euro or in torekes), testify to the fact that taken-for-granted ways of thinking about work had been left behind. So they start to experiment with different ways work. It is important to stress that such questioning is not done in general - discussions were not about comparisons between exchange value and use value, or about the risks and benefits of a global financial economy. Rather, questioning took place in relation to specific situations that were met in the course of the initiative, and they were elicited by the specific artifices present on the site. Artifices are a crucial ingredient in study practices.

Such artifices concern concrete material and technological objects that detach thinking from individual subjects and make it into an event in which all studiers participate. This means that it is no longer possible to argue from an individual subject-position, but only as being bound by the artifice that has made one think. In the case of torekes, the most prominent artifice is the 'fake' money, but one could also think of the allotment garden as an object to think with about the nature of work. These materials make present the problematic situation that first caused people to think (i.c. labor market exclusion due to age, language, etc.) and they force the thinkers not to remain with abstract and general reflections about the matter at hand, but to form thoughts in confrontation with these materials: thought is, so to speak, put at risk by the study material with which studiers think. It is due to the fake bank notes and with the hands in the soil of the allotment garden that people start to question established ways of thinking about employment, unemployment, volunteering, and rewards.

\subsubsection{Attention}

This dynamic of problematization cannot be understood without taking the third educational dynamic of attention into account. Important to stress is that attention in the understanding of Stengers does not only refer to being truly present amidst the people and things on the site, to care for them, but also to take care for the consequences adopting a Jamesian expression. This means that attention is not only 
a present-oriented way of attending to people and things, but also a way of attending to the possible that insists in every such problematic situation, that there is no necessity in the given order of things, and that what is at stake in study practices is the creation of futures that are different from the ones that are perceived as obvious or necessary (Debaise \& Stengers, 2017; cf. James, 1907/2000).

An initiative that aimed at securing an imagined future (creating and sustaining an additional economy in a deprived neighborhood) turned out to gather a public of studiers that felt they should "stay with the trouble" (Haraway, 2016, p. 4) and make themselves truly present in the myriad of ways people in this neighborhood actually try to earn their living. As a complementary currency, torekes itself enhanced processes of attention. Indeed, breakdowns of how the labor market usually functions are built into torekes. For example, the relationship between work, productivity and salary is disrupted because the level of remuneration per hour is not linked to the efficiency of the work performed. In the words of one of the community workers:

People work at different paces. An elderly lady in her sixties who regularly works on the fields, well she works at her pace and he [another volunteer], well, he will probably work ten times as fast but they do earn an equal amount of torekes and nobody makes a fuss about it (Depraetere et al., 2018, p. 101).

The torekes initiative brings glitches in the taken for granted assumptions of the labor market and provokes a space of possibilities. In doing so, the torekes also challenges the taken for granted policy logic concerning activation towards the regular labor market. As we have showed, a committed group of inhabitants has been working on a regular basis in the public space, at least partially stimulated by the currency. Those people are often the very same people that policy makers and institutions for job placement refer to as people who can no longer socially or economically activated:

What I find remarkable is that a lot of these volunteers have stayed over the years. But they are the same people who have been written off by the labour market. According to the VDAB [Flemish Office for Labour Market Mediation and Job Training], they can no longer be activated. But they come here to work for one Toreke an hour, which is a lot less than they would get at any other job... How come? This is difficult to explain to the outside world... (Depraetere et al., 2014, p. 29).

Before the torekes initiative, it seemed very obvious for the community workers that in their work with deprived communities they bounce back and forth between training people to the demands of the labor market or trying to influence policy that sets these demands. But facing what torekes volunteers are doing and saying, this turned to be an issue they actually do not know how to manage anymore. Both the inhabitants and community workers in this case experience in a most concrete manner that the problematic situation of living with a limited wage is turned into a matter that prompts for a new and thoughtful response. That is why they invite 
key players of labor market organizations in and around Ghent to come to work on the communal agricultural fields: a job mediator of the Flemish employment agency, a director of the advocacy organization for SMEs, a consultant of the social economy agency of the city of Ghent, a representative of the socialist trade union and a manager of an urban development company. Afterwards they enlarge their first impressions about earning torekes through a film in which residents tell their story about former work experiences and also the difficulties to find a job. These stories are shot on very different places of the former factory site (e.g. the greenhouse, the football field, the communal agricultural field, the allotment gardens) where residents can show what they are doing while earning torekes. Finally, a debate moderated by a journalist gauges how big or small the gap is between what kind of work is possible in this initiative and in the regular labor market.

\section{TOREKES AS A STUDY PRACTICE}

The analysis of the community building initiative presented in the last section has granted the possibility to describe in detail how a concrete practice constitutes a practice of study. This is due to processes of composition, problematization and attention, which - together - make up an educational practice: people come together and slow down around a local issue in order to investigate it and to discuss about it with the aid of study material (artifices), so as to conceive of new ways to address this issue and to become sensitive for that what is possible in the situation that demands them to think. An issue starts to touch upon people and summons them to abandon taken-for-granted ways of acting and reasoning.

In this last section, we want to return once more to the case of torekes, also to differentiate our reading of this case from other possible renderings, which might sound more commonplace. In particular, we want to show how a study practices approach highlights valuable aspects of this case which remain underexposed when we would analyze torekes solely from a sociological or a political (and not an educational) perspective. Ultimately, our aim is to argue that study practices such as torekes provide a response to the challenges outlined by Latour at the beginning of this article.

\subsection{Social cohesion, subjectification, study}

First, it is possible to view this initiative from the point of view that what is at stake is the enhancement of social cohesion. Such a perspective is not uncommon to policy makers and is often endorsed by many of the community workers that were involved in the torekes project. After all, the inhabitants of the Rabot-Blaisantvest neighborhood could experience in an informal way how people can live together with differences. What is highlighted then is that people can turn a situation of exclusion into a strong experience of belonging and interrelatedness. This is thanks to 
learning to adapt to the complementary currency rules, which allows for restoring an endangered community life in a globalized society. From this rather nostalgic perspective, the shared involvement of a diverse group of people on this place is pictured as a so-called investment in social contacts in order to decrease prejudices towards each other and make new connections possible. One of the volunteers, for instance, observes:

It used to be each group, each culture relating to itself. But here they come together and that's what is so nice about it. Before, those Turkish people, I didn't know them because I don't speak any Turkish. Now it doesn't matter, whether they speak Turkish or whatever... You learn to communicate with each other, with signs and gestures! Those Turkish people also make an effort to make themselves understandable. We'll get there in the end (Depraetere et al., 2018, p. XX).

In view of such observations, one could make an analysis of how a particular rule gets, often tacitly, installed and how, due to this rule, a complex of things, people and activities starts to operate smoothly, coherently and consistently. Such a sociological account dovetails with the rule-based practice theories we discussed above (in section 3.1.). However, such an analysis ignores the many interesting moments which we highlighted in our own rendering of the case, which precisely offer the opportunity to take the risky path of thinking beyond the confines of already established definitions of the problems present in the Rabot-Blaisantvest neighborhood and the solutions that seem obvious.

A second rendering, and one which does take this possibility of newness into account, is to give a political account of this initiative. Interestingly, the case of torekes has been interpreted in such terms by researchers who have conducted fieldwork on the torekes site. Drawing on the work of Rancière, they magnify one of the questions that one of the inhabitants raised during a discussion, so as to show how this initiative brought forward a moment of political emancipation (Depraetere et al., 2018). As already mentioned in our analysis in the former section, this person asked why they were rewarded torekes for their voluntary work, instead of the regular currency Euros which would allow them to buy commodities from bigger companies (instead of being restricted to local shops and services). Depraetere et al. (2018) argue that such an intervention radically interrupts the existing societal order, even to the point that social cohesion is at peril. Put in Rancièrian terms, the current 'police order' is interrupted by people who were not supposed to have a voice, but who take a voice anyway and hence verify equality. As such they make something possible that was unthinkable under the parameters of thought set by existing societal order. People who had no part to play in this order, now gain political agency and become subjects. This act of political subjectification marks a precise breach in time and opens up a moment of emancipation. As such, a Rancièrian account seems the opposite of the sociological one. 
We think, however, that this view misses out on a vital element that is present in this practice, and which is about creating a common world. More than merely interrupting the given situation, it could be argued that the inhabitants of the neighborhood actually take care of the place and the situation they are in and want to stick with it - and 'stay with the trouble' - albeit in new and unforeseeable ways. Working together on the fertile soil spilled out over the former factory site and being paid in torekes, made the inhabitants of the neighborhood hesitate and think about questions of work, employment, volunteering, and food production. Study practices have a different relation towards the present and the future than it is the case in a social cohesion or a Rancièrian approach. Study practices are not about disrupting the present, but about slowing down and going on. Moreover, rather than trying to arrive at an already agreed-upon future, the study practice made it possible to start conceiving of futures that are different from the ones that are desirable according to socio-economic policies. Due to the specific mode of inhabiting the place, the torekes initiative allowed for, people to become attached to the site, to take care for it, and to create a common world that contests established conceptions of labor.

To be clear, the perspective of study practices that we put forward does not question the legitimacy or adequacy of sociological or political analyses of this case. However, in view of the problematic that binds us - how to find a place to land - both perspectives leave crucial aspects out of sight. It is our contention that an analysis in terms of study practices allows torekes to come to matter in an educational way in debates about ways of living on a damaged planet. Therefore, in the remaining part of this section, we want to refine our account of the torekes initiative by analyzing it in practice-theoretical terms. We do so by specifying the requirements of this practice and its obligations. Instead of focusing on the rules that grant the practice its consistency and stability (the sociological approach), or on the interruptive moments that come with it (the political approach), our Stengersian account focuses on what is at stake within this practice: the problem in the presence of which a group of studiers risk their thoughts.

\subsection{Requirements and obligations}

We argue that the obligation that makes studiers hesitate is the question what does work entail? This means that the people gathered in the practice start to raise questions regarding the nature of work, and how it can be valued. Questions such as why the rewards are in torekes and not in Euro testify to the fact that thinking is set in motion with regards to issues related to work. Such questions include not only the valuation of work in monetary or other-than-monetary rewards, but also those pointing at aspects of collectivity, playfulness, and solidarity in labor contexts. The obligation is that which makes studiers hesitate and think (instead of making one's voice heard), and also that which makes them diverge (instead of what creates social cohesion and community). 
Furthermore, we argue that three requirements can be discerned that together make up the specificity of torekes as a study practice, namely performing physical labor in relation to the soil, taking care for a communal space, and using the artifice which torekes is. The first requirement concerns the repetitive nature of the work-related activities that unfold on the site. One could consider scraping weeds, watering vegetables, maintaining work equipment, directing a youth football team as a trainer, etc. Such activities involving physical exercise allow people to submit to a rhythm of labor, according to which working the soil, and having a break and a talk together alternate. The rhythmic quality of the work fosters generative relationships between people, animals, tools, and plants on the fertile soil, and make people think about the meaning of work within their everyday lives as they are often unemployed (due to life situation, age, background).

This is related to the second requirement which concerns the collective care that becomes possible for this dense and superdiverse neighborhood. It can be argued that due to the voluntary work done on a former factory site and the use of a complementary currency to reward the work undertaken there, inhabitants and community workers acquire a very concrete sense of what work entails and develop different ways of appreciating or rewarding (monetary or otherwise) what this work could mean. This requirement draws the attention to the voluntary aspect of work in terms of taking care for a shared habitat, instead of being a means for the provision of individual subsistence. Submitting to this requirement makes the studiers sensitive to the ways in which work is related to the creation and maintenance of a shared space for living. The third requirement sheds again another light on the question what work entails in the sense that it directs attention to the way in which work is being rewarded. The artifice of the complementary currency of torekes causes glitches in the commonplace valuations of work (e.g. financial retribution per hour) and makes people think about relevant and meaningful manners of appreciating voluntary work done on the collective soil. This artifice embeds productive activity within local circuits of labor hours, goods, and services. As such, the fact that people raise such kind of questions can never be attributed to the intelligence or cunning of one of the studiers individually but is the effect of an artifice the efficacy of which is to risk taken-for-granted ways of thinking about everything that work entails.

It is important to note here that obligation and requirements never exist in and of themselves or in general. The question (obligation) what does work entail cannot be addressed outside of a context in which this question might come to matter and can only get meaning within the constraints (requirements) set up by the practice. This forces studiers to become attentive to what is at stake and to start feeling the force it exerts on their thinking. In short, the requirements point at those aspects which make it possible for studiers to become attentive to what is at stake within the practice. As such, requirements exist within a reciprocal capture with the obligation. Indeed, the obligation of the practice demands of studiers that they 
perform certain activities, while it is in the course of these activities that studiers that have become attentive to the obligation, start to raise questions, hesitate and think. The question whether it is the requirements or the obligations that come first is an irrelevant question because it is in their interplay and mutual co-becoming that a practice takes shape and studying is set in motion.

\section{STUDY PRACTICES AND THE CREATION OF A COMMON WORLD}

Returning to Latour's question that formed the initial problematic this article aimed to address, namely where to land?, we argue that study practices such as the torekes initiative offer thought-provoking 'landing strips'. Instead of either returning to a bucolic idea of the Local, or promising a far-fetched idea of the Global, instead of either longing for Edenic pasts, or hoping for salvific futures, study practices offer ways of staying with the trouble and make thought creative of futures that are different from the ones that present themselves as obvious or necessary. Rather, by means of concrete experimentation situated in fertile soils, they speculate about what futures might come to matter to the inhabitants of a present that is burdened with questions concerning labor, unemployment, and food production.

In the case of torekes, it is upon the concrete floor of a former factory site that people start to create a common world together amidst crops and questions. As such, the torekes initiative could be analyzed as an educational response to the pressing issue of living together on a damaged planet. This floor serves as a shell to protect against the chemical toxic waste in the deeper layers of the soil, but functions also as a carrier of new fertile soil. Here, people can study the issue what work entails at a particular place. This makes people that are involved start caring for this place, to go on with it, but in ways that defy any pre-given answers. It is within the critical zone of the reclaimed factory site that knowledge and action, thinking and doing get thoroughly enmeshed in view of the creation of a common world.

\section{REFERENCES}

Arènes, A., Latour, B., y Gaillardet, J. (2018). Giving depth to the surface. An exercise in the Gaia-graphy of critical zones. The Anthropocene Review, 5(2), 120-135. https://doi. org/10.1177/2053019618782257

Callon, M., Lascoumes, P., y Barthe, Y. (2009). Acting in an uncertain world. An essay on technical democracy. Cambridge, MA: The MIT Press.

Debaise, D., y Stengers, I. (2017). The insistence of possibles: towards a speculative pragmatism. PARSE, 7, 13-19. https://doi.org/10.3366/edinburgh/9781474423045.001.0001

Depraetere, A., Van Bouchaute, B., Oosterlynck, S., y Vandenabeele, J. (2018). Nurturing solidarity in diversity: can complementary currencies enable transformative practices. In S. Oosterlynck, G. Verschraegen y R. van Kempen (Eds.), Divercities. Understanding 
THE EDUCATIONAL DYNAMICS OF AN URBAN FARMING INITIATIVE

superdiversity in deprived and mixed neighbourboods (pp. 89-112). Bristol: Policy Press. https://doi.org/10.2307/j.ctv92vpp2.10

Depraetere, A., Van Bouchaute, B., Vandenabeele, J., y Oosterlynck, S. (2014). Research report case study: Complementaire munt de torekes in Rabot-Blaisantvest, Gent. http://www. solidariteitdiversiteit.be/uploads/docs/cases/torekesdef.pdf (Consultado el 10/08/2019).

Ford, D. (2016). Communist study. Education for the commons. Lanham, MD: Lexington Books. https://doi.org/10.1080/10510974.2016.1196381

Haraway, D. (2016). Staying with the trouble. Making kin in the Chthulucene. Durham, NC: Duke University Press. https://doi.org/10.1215/9780822373780

Harney, S., y Moten, F. (2013). The undercommons. Fugitive planning and black study. New York, NY: Minor Compositions.

Higgs, J., Barnett, R., Billet, S., Hutchins, M., y Trede, F. (Eds.). (2012). Practice-based education. Perspectives and strategies. Rotterdam: Sense Publishers. https://doi.org/10.1007/97894-6209-128-3

Illich, I. (1973). Deschooling society. London: Penguin Books.

James, W. (1907/2000). Pragmatism and other writings. London: Penguin Books.

Kemmis, S., Wilkinson, J., Edwards-Groves, C., Hardy, I., Grootenboer, P., y Bristol, L. (2014). Changing practices, changing education. Rotterdam: Springer. https://doi.org/10.1007/978981-4560-47-4

Latour, B. (2017). Facing Gaia. Eight lectures on the new climatic regime. Cambridge: Polity Press.

Latour, B. (2018). Down to earth. Politics in the new climatic regime. Cambridge: Polity Press.

Lewis, T. (2013). On study. Giorgio Agamben and educational potentiality. London: Routledge. https://doi.org/10.4324/9780203069622

Lewis, T. (2014). The fundamental ontology of study. Educational Theory, 64(2), 163-178. https://doi.org/10.1111/edth.12055

Masschelein, J. (2017). Some notes on the university as studium: a place of collective public study. In C. Ruitenberg (Ed.), Reconceptualizing study in educational discourse and practice (pp. 40-53). London: Routledge. https://doi.org/10.4324/9781315652214-4

Ortner, S. (1984). Theory in anthropology since the sixties. Comparative Study of Society and History, 16, 126-166. https://doi.org/10.1017/S0010417500010811

Postill, J. (2010). Introduction: theorizing media and practice. In B. Bräuchler \& J. Postill (Eds.), Theorizing media and practice (pp. 1-27). New York: Berghahn.

Ruitenberg, C. (Ed.). (2017). Reconceptualizing study in educational discourse and practice. London: Routledge. https://doi.org/10.4324/9781315652214

Schatzki, T. (2012). A primer on practices: theory and research. In J. Higgs, R. Barnett, S. Billet, M. Hutchins, y F. Trede (Eds.), Practice-based education. Perspectives and strategies (pp. 13-26). Rotterdam: Sense Publishers. https://doi.org/10.1007/978-94-6209-128-3_2

Schatzki, T., Knorr Cetina, K., y von Savigny, E. (Eds.). (2001). The practice turn in contemporary theory. London: Routledge.

Schildermans, H. (2019). Making a university. Introductory notes on an ecology of study practices. Leuven: KU Leuven (Unpublished doctoral dissertation). 
HANS SCHILDERMANS, JOKE VANDENABEELE Y JORIS VLIEGHE STUDY PRACTICES AND THE CREATION OF A COMMON WORLD. UNEARTHING THE EDUCATIONAL DYNAMICS OF AN URBAN FARMING INITIATIVE

Simons, M. (2017). Manipulation or study: some hesitations about post-truth politics. Bildungsgeschichte: International Journal for the Historiography of Education, 7(2), 239-244.

Stengers, I. (2002). A Cosmo-politics: risk, hope, change. In M. Zournazi (Ed.), Hope. New philosophies for change (pp. 244-273). Annandale: Pluto Press.

Stengers, I. (2006). La Vierge et le neutrino. Les scientifiques dans la tourmente. Paris: Les Empêcheurs de penser en rond.

Stengers, I. (2010). Cosmopolitcs I. Minneapolis, MN: The University of Minnesota Press.

Stengers, I. (2017). Civiliser la modernité? Whitehead et les ruminations du sens commun. Dijon: Les Presses du Réel.

Tsing, A, Swanson, H., Gan, E., y Bubandt, N. (Eds.). (2017). Arts of living on a damaged planet. Minneapolis, MN: The University of Minnesota Press. 